\title{
THE TRANSITIONAL CHANGE ON THE IMPLEMENTATION OF ISO 14001:2015 IN COPPER ORE MILL - CASE STUDY
}

\author{
Arif Susanto ${ }^{1,2}$, Nur Budi Mulyono ${ }^{2}$ \\ 1 Doctoral Program of Environmental Science, School of Postgraduate Studies, Universitas Diponegoro, 50241, \\ Semarang, Indonesia, e-mail: arifssnt@yahoo.com \\ 2 School of Business and Management, Institut Teknologi Bandung, 40132, Bandung, Indonesia, \\ e-mail: nurbudi@sbm-itb.ac.id
}

Received: 2017.06.16 Accepted: 2017.08.01 Published: 2017.09.01

\begin{abstract}
The transition process of implementation standard for environmental management system (EMS) ISO 14001 : 2015 lasts for three years, requiring every organization to adopt the latest version by September 2018. The objectives of this research is to describe and analyze the stages done by copper ore mill. This research used a concept analysis method, which focused on and could be basically defined to examine the basic elements of widely used concept to clarify ISO 14001 :2015 standards characteristics and relations. The result of this research provide a conceptual framework based on the standard of ISO 14001:2015 - EMS : Requirements with Guidance for Use, where this framework consists of steps to design the transition change from EMS ISO 14001 :2004 to its 2015 new version. The description of every step is expected to give understanding and model for organizations that must conduct transition and for the ones that will start implementing the EMS.
\end{abstract}

Keywords: aspects; EMS standard; conceptual framework, ISO 14001:2015; transition change.

\section{INTRODUCTION}

Transition change is necessary as a more significant response to environmental change. A simple change of 'what is', transition change replaces 'what is' with something different as a whole. Transition change starts with management acknowledgement that existing problems cannot be solved or an opportunity cannot be pursued, so something in the current organization operations need to be changed or a better service is created (Andersen and Andersen, 2001). It is a continuous alignment process of an organization with its environment (Davidson, 2009) and a process to manage the effects that arise.

ISO 14001:2015 is applicable to any organizations, regardless of types, size, and nature. EMS applies to the environmental aspects of its operations, products, and services that the organization sets that can control and or influence by taking account of the perspective of the life cycle (Shehabi, 2016). EMS helps organizations identify, manage, monitor, and control their environmental issues in a 'holistic' manner (ISO-a, 2015). It requires that an organization considers all environmental issues relevant to its operations.

EMS includes the need for continual improvement of an organization's systems and approach to environmental concerns (ISO-b, 2015). The standard has recently been revised and there will be a three year transition process certification with key improvements such as the increased prominence of environmental management within the organization's strategic planning processes, greater input from leadership, and a stronger commitment to proactive initiatives that improve environmental performance (ISO-a, 2015).

Copper ore mill is a process business unit in separating the mine minerals by using a complex process, high technology and quite a lot of man- 
power, where this activity can possibly be influential to its environment (Susanto et al, 2012). Furthermore, in its environmental management, it uses ISO 14001:2004 standard management system; therefore, it is necessary to conduct change management related to ISO 14001:2015 implementation plan.

The success of this change is highly subject to how the change management process stages are done (Newton, 2007). One of the big change for ISO 14001:2015 is that it brings environmental management and continuous improvement into the core values of an organization, so the standard of the new management system is an opportunity for organization to conform its strategic direction in environmental performance improvement.

In order to address this issue, the transition process in the EMS at the copper ore mill must be planned and managed skillfully so that the change can occur effectively to achieve its objectives. The problem that may appear from this change is planned changes to ISO 14001:2015 with regard to the use of life cycle perspectives and risk-based thinking.

\section{METHODS}

The conceptual framework in this research to reach roadmap outline is based on standard of ISO 14001:2015 Environmental Management System - Requirements with Guidance for Use. The framework consist of steps to design a transition change EMS ISO 14001:2004 to new version 2015 as depicted in Figure 1. Research methods used concept analysis methods, because its utilized in business studies (Firth et al, 2015) which focus and could be basically defined to examine the basic elements of a widely used concept to clarify ISO 14001:2015 standards characteristics and relations.

In business studies, interpretative research of concepts belongs to the interpretative paradigm of organization and management research, but can also classified as types of conceptual research methods (Nuoponen, 2010). Target-oriented conceptual problem solving, forming concept through analytic and synthetic reasoning by using existing concept and insight are used in this research. The selected resource from ISO define concept analysis each from the point of view.

Analysis process starts with general considerations and continue to the next step consist of structuring a concept system and analyzing all data systematically by conceptual framework that was elaborated based on ISO EMS new version guidelines. Elaboration means going through collected information on concepts according to preliminary concept system and establishing their content and delimiting concepts from other concepts in the same concept system.

The method to collect data was observation method with documentation study where data collection was done by systematically collecting, observing and recording the investigated findings. The tool used to collect data was a checklist sheet

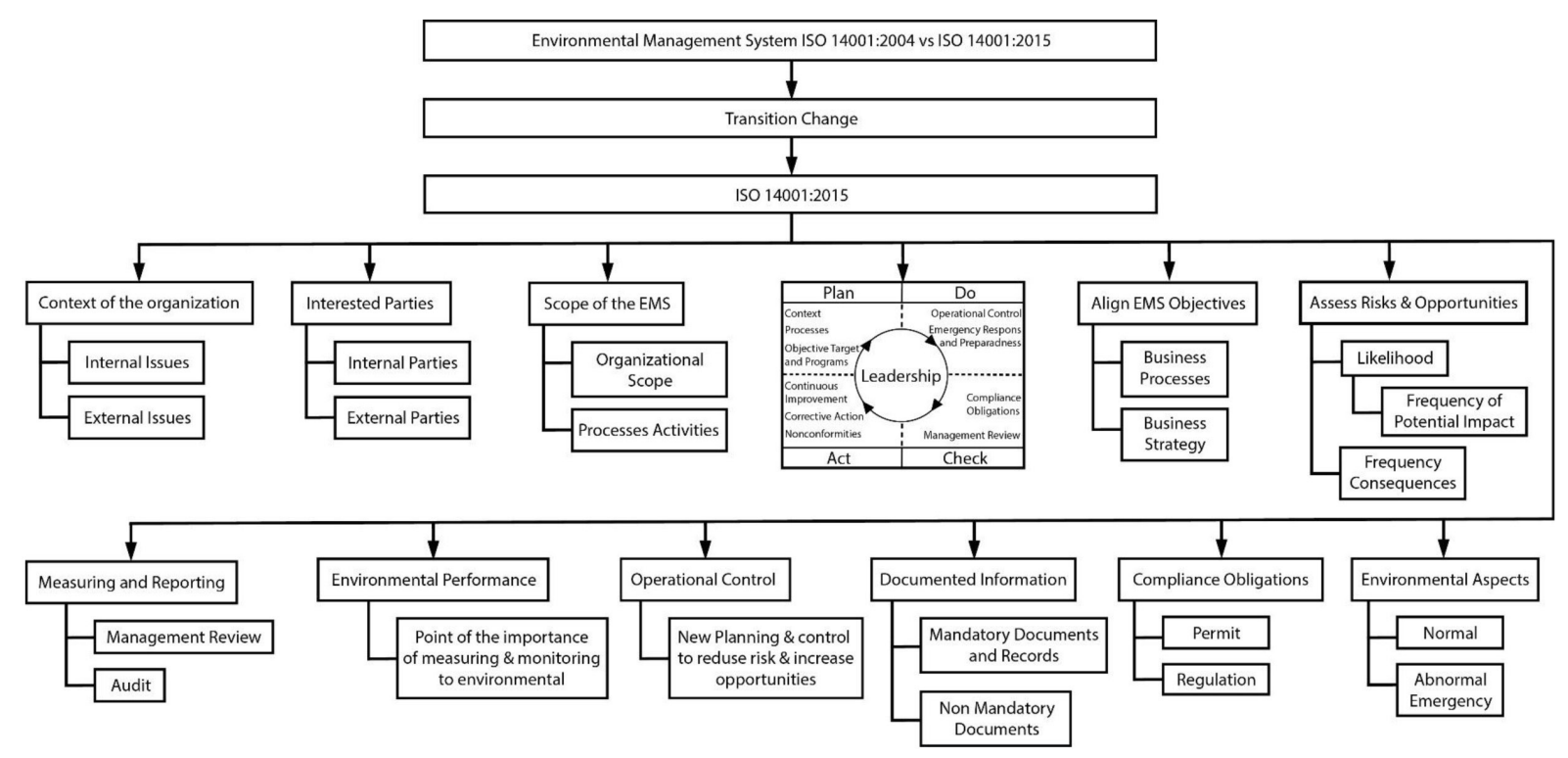

Figure 1. Conceptual Framework

Source: elaborated by the authors based on ISO 14001:2015 guidelines. 
on conformity between the real condition with the clauses in ISO 14001:2015. Afterwards, gap analysis was done upon the checklist and we could identify which requirements that had been complied and the ones which had not been complied.

Document study was complementary for the use of this observation method, in qualitative research, where the credibility of research result should be higher if using documentation study (Susanto, 2017). Furthermore, there were several benefits of using this method: documentary materials were available and ready to use, no need research cost but only need some time to study it, could be a triangulation to check data conformity and was the main material in historical research.

\section{RESULTS}

Alike all ISO management system standards, ISO 14001 also covers the need for organization system improvement as well as a continuous approach to environmental problems. In ISO $14001: 2015$, there is a key element of improvement that is specified for environmental management that covers organization strategic planning process, leadership and proactive initiatives that improve the environmental performance. An organization must take a strategic approach to improve its environmental performance (Susanto, 2017).

The use of ISO 14001 standard helps in showing the current and future compliance with the law and regulation requirements; improving leadership and employee involvement; improving company's reputation and stakeholders' trust through strategic communication; achieving strategic business that aims to combine environmental issues into business management; providing competitiveness and benefits through efficiency improvement and cost reduction; encouraging a good environmental performance for the suppliers by integrating them into the ones that focus on communication strategies in organization business system (ISO, 2015).

Change is a transformation from current condition towards the expected condition in the future, i.e. a better condition. The objective of change management is to make organization more effective, efficient and responsive upon the change happening in the organization. There are four main dimension of the base of change management perspective: (1) related to the concept on change process; (2) related to contexts and un- certainty; (3) related to the content and scale of change to be done; (4) and related to the method and strategy chosen to manage the change. The concept about change process will give an understanding on change process that can be a base in creating a condition that enables the creation of a change as depicted in Figure 2.

Management conducts various time investments and other worthy resources to change the ways organization operates. This planned change is defined as deliberate structural innovation planning and implementation, policy and new objectives, climate and operation style. Inside the change process, there is an individual that is responsible for leadership roles in the process of change management. The planned change is led by a top management in organization, but all the members of the organization can take role and initiative necessary to give contribution based on their abilities for the success of change process (Yukl, 2002).

Strategy is made to accelerate the achievement of an organization goal. The direction and coverage of organization in long-term period are to achieve organization benefits through configuration of all resources they have in order to be able to handle environmental challenges as well as fulfilling business environmental needs and the expectation of related parties. Strategy formulation conducted is to develop the organization vision and missions, stating strategic objectives and designing strategies to achieve those objectives.

There are five phases in the system thinking mentioned above that affect the transitional change from ISO 14001:2004 into ISO 14001:2015 in the environmental management system at copper ore mill:

- Phase A - Output: Phase that defines clearly the objectives to achieve by defining the vision forward.

- Phase B - Feedback: Phase that is used to see whether the objectives have been achieved.

- Phase C - Input: Determining the gap between the current conditions with the expected conditions so that the steps to achieve them can be determined.

- Phase D - Throughput: phase that determines the necessary steps to reduce the gap and to realize the objectives stated in phase A.

- Phase E - Environment: Conducting external and internal identifications that affect the change, where the result will give direction and how much the change to be done. 


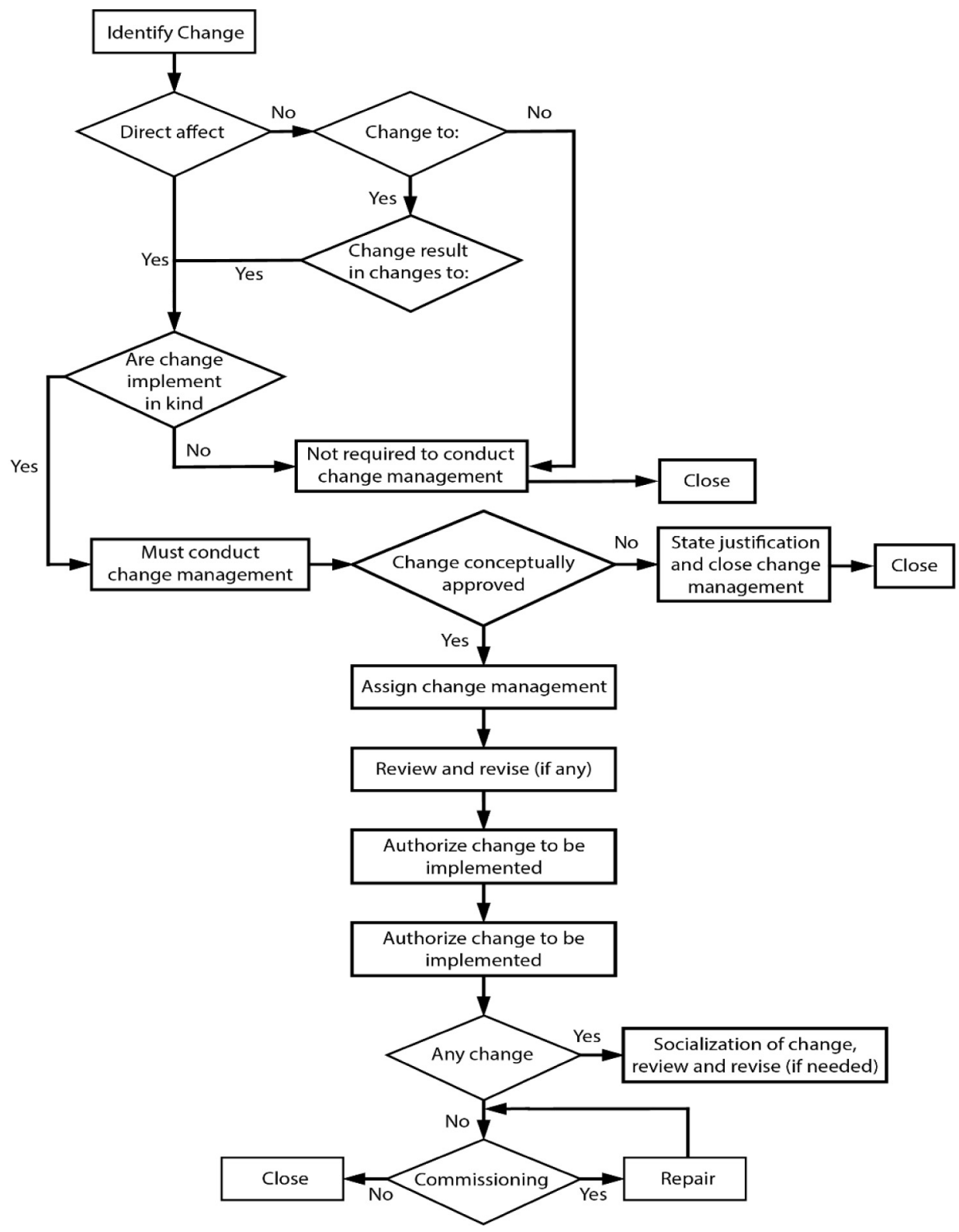

Figure 2. Change management through continuous improvement and environmental management review

\section{Context of the Organization}

Clause 4.1 and 4.2 procedure for determining context of the organization are non mandatory document that can be used for ISO 14001:2015 implementation and it is the first requirement of the standard and how they affected the EMS. It is decided to approach the requirement with a SWOT analysis, and depicted in table 1.

\section{List All Interested Parties}

In a broad line, the causing factors of change can be categorized into two, i.e. external factors and internal factors (Wallace and Szilagyi, 1982). External factors are the change causes coming from externals, or often called environment. Organization is responsive to the change happening in its environment.

Therefore, an organization seldom makes a big change without a strong encouragement from its environment. Meanwhile, internal factors are the change causes coming from inside the organization. Some of the organization change causing factors that belong to external factors are the change of ISO 14001 environmental management system standard used by copper ore mill and the government regulations related to environmental management. Both external and internal interested parties that will affect this change management. List all interested parties as a part of determining the organization depicted in table 2 . 
Table 1. Approach requirement of the EMS standard

\begin{tabular}{|c|c|}
\hline Strength & Weakness \\
\hline $\begin{array}{l}\text { - Environmental issues awareness } \\
\text { - } \text { Competent and experiences employees } \\
\text { - } \quad \text { Long-term contracts of work (CoW) }\end{array}$ & - ISO 14001 certification according to old version \\
\hline Opportunities & Threats \\
\hline 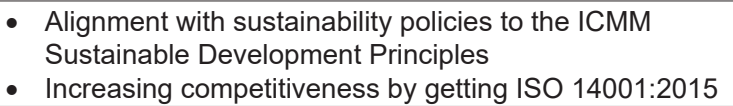 & $\begin{array}{l}\text { - Violation to Environmental Impact Analysis commitment } \\
\text { - Failing ISO 14001:2015 certification }\end{array}$ \\
\hline
\end{tabular}

\section{The Scope of the Environmental Management System (EMS)}

Since the standard was implemented, the organization was considering expanding its business to concentrating and/or milling processes, so they are included in the scope of the EMS. Scope is defined as the area or range covered by activity and its use within the ISO 14001:2015 in clause 4.3 encourage to consider all potential effects that performance of the EMS. And consider all factors such as internal and external issues; compliance obligations; the organizational units; functions and physical boundaries (in terms of how copper ore mill actually operates); processes activity and products; to assess the impact within the organizational scope.

The EMS cannot be effective without control of its components, and demonstration of any influence over the external aspects. The ISO 14001:2015 advises that the scope should be maintained and be available to interest parties as mandatory documented information and records required. The scope of EMS allowing organization to make a critical information available to

Table 2. List all interested parties

\begin{tabular}{|c|c|c|}
\hline \multicolumn{3}{|c|}{ Interested Parties } \\
\hline \multicolumn{2}{|c|}{ External Party } & Needs and Expectations \\
\hline - Consumers & - Buyers & $\begin{array}{l}\text { - } \text { Green Supply Chain } \\
\text { - } \text { Sustainability Reporting Initiatives } \\
\text { - } \text { Business to Business (B2B) }\end{array}$ \\
\hline - Regulators Legislators & $\begin{array}{l}\text { - Ministry of Environmental and } \\
\text { Forestry } \\
\text { - Ministry of Energy and Mineral } \\
\text { Resources } \\
\text { - } \text { Minstry of Industry } \\
\text { - } \text { Ministry of Health } \\
\text { - Environmental Impact Control Agency }\end{array}$ & $\begin{array}{l}\text { - Compliance with environmental protection } \\
\text { - Compliance with occupational health and } \\
\text { - Comangliance with chemical management } \\
\text { - Complations } \\
\text { - Cogulations } \\
\text { - Compliance with industrial health regulations } \\
\text { - Compliance with hazardous wastes } \\
\text { - Complan waste water regulations }\end{array}$ \\
\hline - Shareholders & - Owners & $\begin{array}{l}\text { - ISO } 14001 \text { certified } \\
\text { - Eco-friendly image }\end{array}$ \\
\hline - Community & $\begin{array}{ll}\text { - } & \text { Local } \\
\text { - } & \text { National } \\
\text { - } & \text { International }\end{array}$ & - Environmental disclosure \\
\hline - Special interest group & - NGO & - Environmental disclosure \\
\hline - Media & - Mass Media & - Environmental disclosure \\
\hline \multicolumn{2}{|c|}{ Internal Party } & Needs and Expectations \\
\hline - Top Management & - Board of Directors & $\begin{array}{l}\text { - } \text { ISO } 14001 \text { certified } \\
\text { - Eco-friendly image } \\
\text { - } \text { Efficiency uses on resources } \\
\text { - Efficiency uses on raw materials } \\
\text { - } \text { Reduce a company's costs } \\
\text { - } \quad \text { Advantage in global market } \\
\text { - } \quad \text { Reduced insurance premiums }\end{array}$ \\
\hline - Suppliers & $\begin{array}{l}\text { - Vendors } \\
\text { - Contractors }\end{array}$ & $\begin{array}{l}\text { - Reducing the amount of potentially } \\
\text { hazardous substances } \\
\text { - Advantage in global market }\end{array}$ \\
\hline - Employee & - Workforce & - Safer internal environment \\
\hline - Union & - Union & $\begin{array}{l}\text { - Workplace safer and they are could } \\
\text { contributing to the environmental effort }\end{array}$ \\
\hline
\end{tabular}


shareholders, stakeholders, and external parties, also allow an organization to continually review and improve the scope of EMS itself. Compliance at audit time will also be a problem if the organization cannot demonstrate that the scope has been properly considered, defined, and documented.

The transitional change on the implementation of ISO 14001:2015 at copper ore mill can be categorized into technological change where it includes new products and process. This change varies which covers items related to the establishment of new tools and ways in various production process. Besides being categorized into technological change, the transitional change can also be categorized as externally environmental change, i.e. change on the international standards. Meanwhile, organization's internal change covers strategy and environmental policy changes.

\section{Leadership and Review of the Environmental Policy}

Organization component that often becomes one of the organizational change targets is organization structure that consists of:

1. Formulation in certain formula or aspect on the defined objectives.

2. Change in mission to accomplish.

3. Change in the formulation, nature and type of operational main tasks, assignments and activities.
4. Change in the workload assigned to the organization as a whole or certain component of the organization.

In ISO 14001:2015, leadership as part of context of the organization is illustrated in Figure 3.

Change in the field of organization leadership occurs with or without a change in organization structure. In the scope of environmental management system, it covers:

1. Planning, this is related to the sensitivity and responsiveness on the changes that occur in various field outside the organization whose influence is felt in organizational functional task execution. These changes have implications on the quality, type and form of information needed to develop a plan which in turn may require a change.

2. Furthermore, the analysis and formulation of the policy that is derived into Environmental Policy that states several objectives comply in all material respect with applicable environmental laws and regulation, which voluntary commitment to which it subscribe; seeks means to prevent environmental pollution; seek continuing improvement by implementing a management system that sets objectives and targets, which are based on valid data and sound science, by reviewing targets sets in the Environmental Management Plan and Environmental Monitoring Plan and by regular internal and external audits.

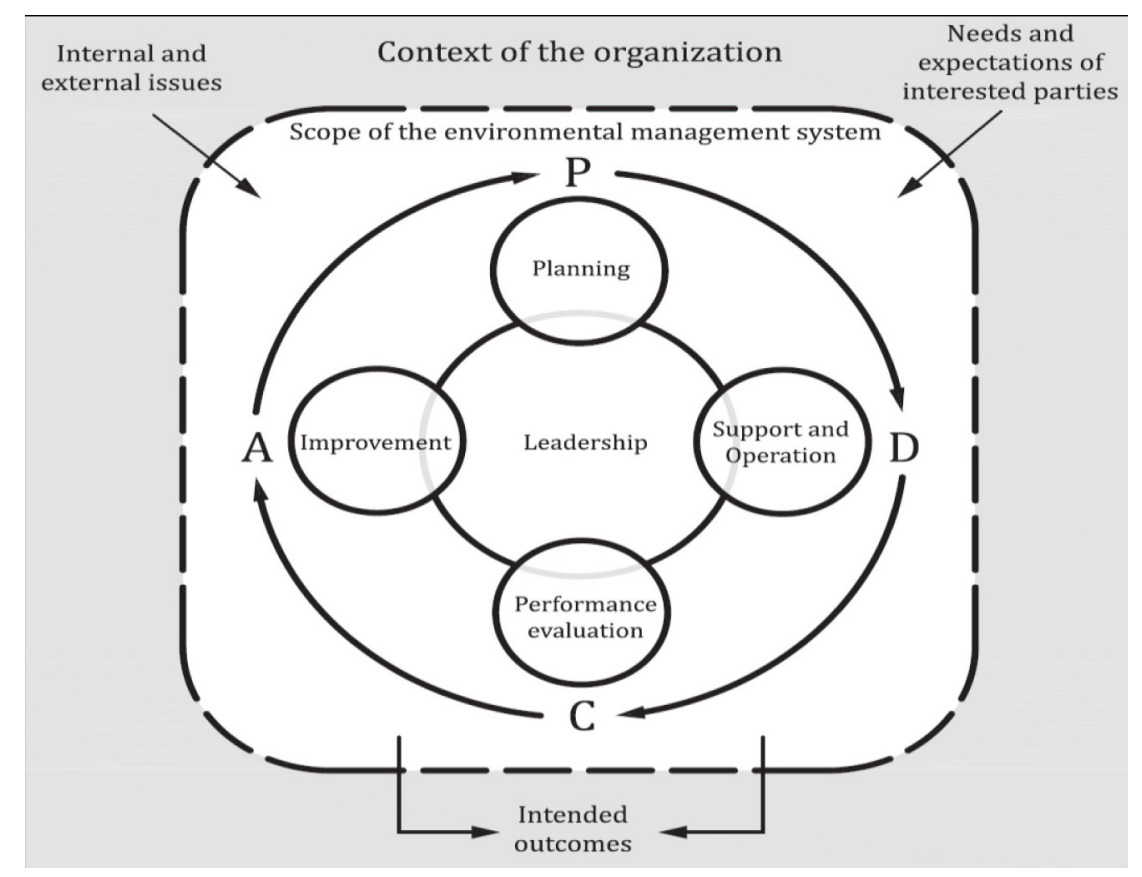

Figure 3. Context of the organization in ISO 14001:2015.

Source: ISO, 2015. 
3. Ensure that environmental considerations are an integral part of all planning, engineering and operations; work with community near our operations by applying mutual respect and developing active partners; promote energy efficiency and responsible 3R (reduce, reuse and recycle) and disposal of products used in the operations; contribute to conservation of biodiversity and integrated approaches to land use planning. Ensure a policy is documented, communicated to all employees and persons working on behalf of the organization, and made available to all interested parties.

4. Support and Operation, this involves a change in work procedures in decision making process. Similar with policy formulation process, decision making process is also related to the management and the leadership style of the organization leaders. In decision making process, the nature and the form of involvement from various parties need to be formulated strictly and clearly, including every necessary change for work efficiency and effectiveness both in individual level and organizational level.

5. Performance Evaluation, this is a form of monitoring function in an effort to improve work efficiency, effectiveness and productivity. Eliminating or reducing the deviation of the previously stated plans, for example, is an effort to gather facts and operational data with information technology can improve monitoring efficiency that later on will improve organization efficiency.

6. Improvement, organization shall accept the change that will occur when a faith arises from themselves that the change will be an advantage or disadvantage for them. Furthermore, organization leaders need to always search and find new procedures that re beneficial for the organization and provide ease for their members.

In clause 5, i.e. leadership, a change leader must be able to be a champion: (1) able to socialize the vision and to encourage every individuals in the organization to achieve the vision; (2) able to play the role not only as a knowledge worker but also as a knowledge broker; (3) able to spread the knowledge towards other members.

Top management has a final responsibility for the function of environmental management system for the ones mentioned in clause 5.1, by making an active effort and getting involved in understanding significant critical risks and opportunities in terms of environment; status of organization compliance with the interested parties; and various elements from environmental management system. Making regular contacts with project leaders as well as evaluating their progress and, if necessary, giving a guidance at the right time and providing necessary resources. In addition, giving information on the operations condition through internal audits, which at the same time, can emphasize the importance of environmental issues for the employees.

The role of the leaders in change process can be regarded as the source of change process success, where the direction and the objectives of the change are usually determined by the leaders to be executed by the whole organization members later on. Furthermore, leadership strategic function is to influence organization's culture (Metcalf and Metcalf, 2005) so that it always integrates environmental factors as part of management function, developing vision, conducting change on the environmentally-oriented practices in every process in copper ore mill (Yukl, 2002).

\section{Align EMS Objectives with the Company's Strategy.}

Involvement of the top management in defining environmental objectives, target and program (OTP), the company must also define plans for achieving those OTPs. Environmental Section developed the framework for planning achievement of the OTP. The plan included defining the responsible person (PIC, personnel in charge), a set of activities that would lead to achievement of OTP, necessary, resources and datelines.

\section{Assess Risk and Opportunities}

In identifying and determining the environmental aspects and impacts, referring to risk assessment method (Jr. Bird and Germain, 1996) with four-cells risk assessment matrix, and calculating the life cycle according to the clause in clause 6.1.2 of ISO 14001:2015 environmental management system standards (ISO, 2015). Meanwhile, life-cycle assessment or usually known as life-cycle analysis is the continuous and interrelated stages in product system and/or services, starting from material procurement or making from natural resources to the final disposal (ISO-a, 2006; ISO-b, 2006). 
This risk assessment method considers normal, abnormal and emergency conditions that can possibly happen, and becomes a part in the method (ISO, 2015). Normal condition refers to the regular or expected condition from an organization activity or plan operation, while abnormal condition refers to the unplanned or unexpected condition that is not part of the organization operation plan, and emergency condition refers to an unexpected or serious, urgent and sudden situation that requires immediate action. Environmental management system is a system that is dynamic and able to follow the dynamics or development on the related parties, therefore organization has to be able to follow the development by proofing that the environmental aspect list is always updated, either when there is a development from external factors like environmental regulation change or when it is done regularly to accommodate changes in the organization.

According to clause 6.1.2 in ISO 14001:2015, copper ore mill must guarantee that the aspects related to their important aspects are considered in defining environmental objectives, and keep paying attention to the followings:

1. Considering life cycle in determining environmental aspects and impacts by considering changes including planned development, process and whenever there is a modification.

2. Considering normal, abnormal and emergency conditions that may possibly happen.

3. Determining the method to define important environmental aspects so that copper ore mill can make follow up programs and actions on the results of environmental aspects and impacts identification that have been done previously.

In ISO 14001:2015 standard implementation performance and indicators, there are several parameters and indicators of environmental management system performance stated from several items illustrated in Figure 4.

\section{Significant environmental aspects}

Copper ore mill shall identify environmental aspects from its operational activities according to the requirements and determine the environmental aspects that significantly give impacts on the environment. And to ensure that the control has effectiveness and efficiency in achieving targets, monitoring and measurement have to be conducted.

\section{Compliance obligation}

Compliance obligation consists of law regulations and other requirements, which regulate the obligations that must be complied by copper ore mill, i.e. key parameters stated in the environmental documents such as Analysis on Environmental Impacts, environmental permits etc.

\section{Operational Planning and Control}

In order that the environmental aspects are in line with their objectives, copper ore mill shall conduct monitoring and measurement from the operation activities, through monitoring on the standard operating procedures (SOP) compliance, abnormal operation condition, operation implementation to the incompetent personnel, etc.

\section{Identify and Evaluate Environmental Aspects}

According to clause 6.1.2 in ISO 14001:2015, copper ore mill is required to conduct identification of environmental aspects from its operations. The identification of environmental aspects and impacts is one of the initial processes in environmental management. Based on the identification results, the important aspects in a process on each activity unit in copper ore mill can be defined, so an environmental control and management planning program, as well as the follow up actions in the important aspects handling.

The identification result is a list of environmental aspects and impacts that cover the whole environmental aspects comprehensively, in normal, abnormal and emergency conditions, as well as all components explained per part of production activity etc. Environmental aspect is defined as part of activity that interacts with the environment while the impact is the result of an aspect. In other words, there is a cause-and-effect relation between environmental aspects and impacts.

For example, kiln operation in lime production activity, where this lime is used as the material for production process to improve mineral recovery, is one of the main activities in the lime plant consisting of sub-activities that interact with environment or create impacts such as dust emission. Gas emission resulted in the calcination such as $\mathrm{SO}_{\mathrm{x}}, \mathrm{NO}_{\mathrm{x}}$ and mainly particulate is environmental aspect that can create impacts in a form of air pollution. Meanwhile, other aspects from lime production activity, i.e. used oil and diesel oil usage as lime production fuel mixer that 


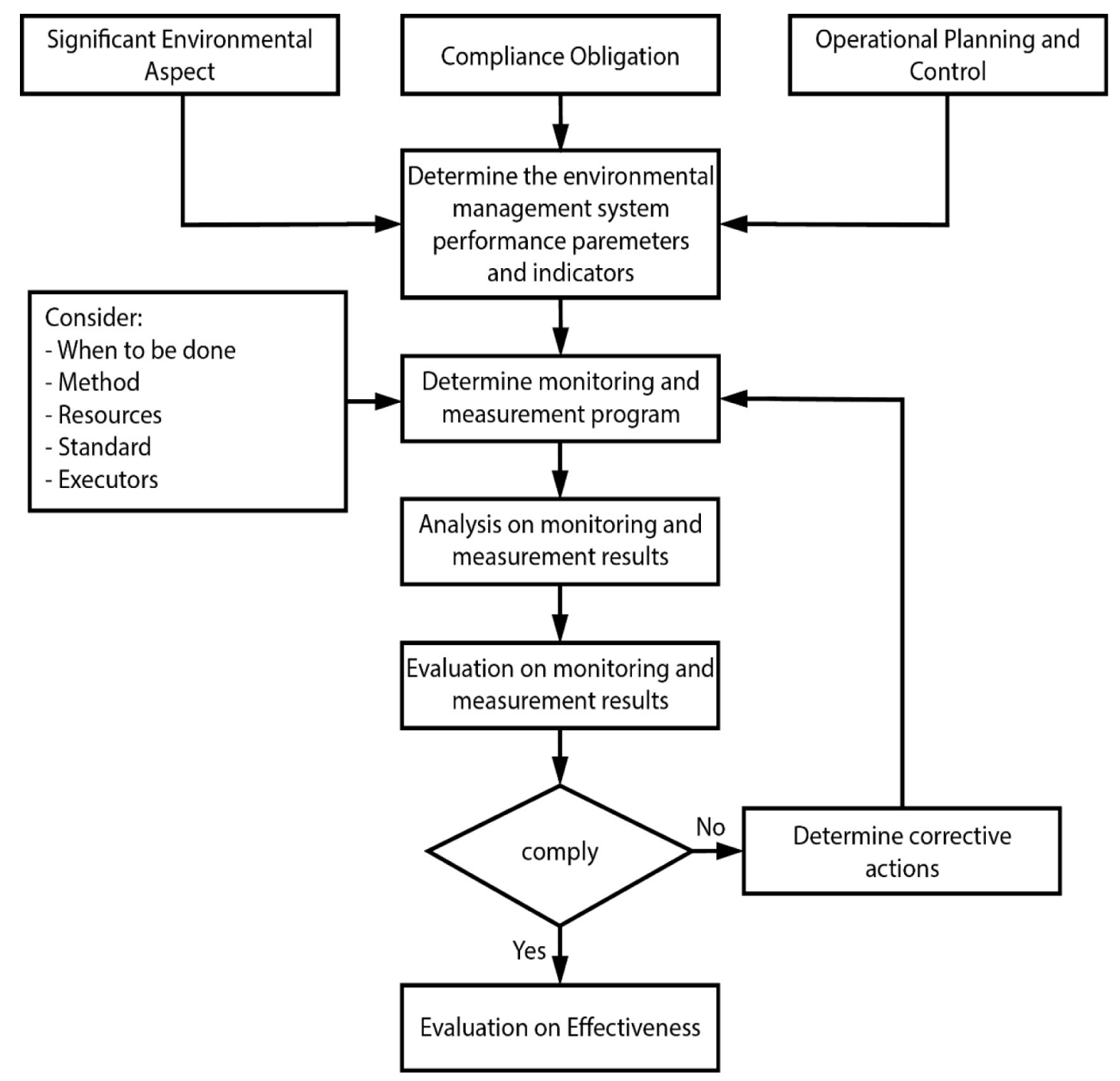

Figure 4. Indicators and performance of environmental management system

can create impact such as oxidation gas emission (Susanto et al, 2016).

Another example from these aspects is laboratory activity in a form of metallurgy analysis that has sub-activity or environmental aspect like chemicals addition, fire assay waste generation (Susanto et al, 2013; Susanto et al, 2015), which, if the impact creation process is examined, these activities are categorized as the environmental aspects that create land and water pollution impacts from hazardous waste generation and air pollution from the potential of exhaust dust release which can potentially become a hazard on occupational health. It can also be seen here that several aspects can cause one or several types of environmental impacts, i.e. air pollution, water pollution and/or land pollution.

Aspects in abnormal condition of activity can exist when, for example, machinery and equipment maintenance activities are conducted so the environmental impacts are not from normal activities, i.e. used oil and grease spills, used spare part disposal, chemically contaminated waste, etc. Meanwhile, emergency condition contributes environmental aspects in the form of particulate 'blow up' to the air due to operational temperature that is too high, which may exceed threshold values stated in the environmental permits. These three conditions (normal, abnormal and emergency) must be listed and differentiated between the two conditions, where emergency condition is a beyond-normal condition that gives sudden huge impacts and cannot be prevented except to reduce the impacts aftermath.

The identification must be done not merely limited to the operational activities related to the largest waste source, but reaching the aspects of their products. The examples that have been mentioned above are aspects that appear from production main activities. While aspects from products 
have wider coverage, such as overview on the products when pumped from mill tower through concentrate pipeline system, dewatering process, dry concentrate storage in barns, and concentrate product loading to the transporting ship. This process can cause impacts to the environment. Land and water pollution appear from the potential of pipeline leak, air pollution from concentrate particles and gas emission from the oxidation of used oil and diesel fuel mix (Susanto et al, 2016).

Various types of impacts can clearly be caused by those aspects and have risky category, so this is an example of product aspect classified as significant aspect. After it is clear for identification coverage, copper ore mill can conduct evaluation on the whole aspects to determine the aspects classified as important aspects, or the ones that will get handling priority based on their risk study. This stage is a critical stage and strongly determines the success and effectiveness of environmental management system implementation. In ISO 14001:2015 environmental management system standard, it does not require a certain risk assessment method and evaluation, including whether it has to be with qualitative or quantitative method, however what needs to be made is a method that is appropriate with the complication level of the organization activity itself.

\section{Compliance Obligation Evaluation}

Compliance obligation refers to two items, i.e. law regulation and other requirements. Law regulation requirements covers: (1) requirements from government body or other relevant authorities; (2) international, national and local law and regulations; (3) requirements stated in the permits; (4) orders or regulations from law bodies; (5) court or administrative court decisions. Meanwhile, other requirements are the requirements identified by respective and related parties with the environmental management system where organization must comply and/or dan choose to adopt, for example agreements with community of non-governmental organization; agreements woth public authority or customers, voluntary labelling or environmental commitment; agreements that exist based on contract agreements with organization and relevant organization standards.

Parameters of impacts and costs represent economic interest or company business, so according to the ISO 14001:2015 objectives that there has to be a balance between economic interest and environment. The final product of aspect evaluation stage is the list of environmental important aspects, which may be listed from the most important to the less important, based on the achieved score as described in table 3.3. It shows that the company has succeeded creating priority of many works and is the objective of clause 6 , i.e. Planning on ISO 14001:2015.

Identification of environmental impacts is the implementation of clause 6.1.2 from ISO 14001:2015 environmental management system where the comprehensiveness of system, coverage compliance and work priority are resulted from this standard clause. The success of a system very depends on a good understanding on the environmental aspects and impacts. The result of risk assessment can be used as a reference and data information in operation control determination and administration control to minimize the risks related to the impacts of environmental aspects in copper ore mill.

\section{Operational Control}

Copper ore mill already had some operational controls, and since the reassessment of environmental aspects was conducted required

Table 3. Mandatory documents and records required by ISO 14001:2015 in Copper ore mill

\begin{tabular}{|c|c|}
\hline Documents & Records \\
\hline $\begin{array}{l}\text { - } \text { Scope of the EMS (Clause 4.3) } \\
\text { - Environmental Policy (Clause 5.2) } \\
\text { - Risk and Opportunities (Clause 6.1.1) } \\
\text { - Criteria for evaluation of significant environmental aspects } \\
\text { (Clause 6.1.2) } \\
\text { - Environmental aspects with associated environmental } \\
\text { aspects (Clause 6.1.2) } \\
\text { - Significant environmental aspects (Clause 6.1.2) } \\
\text { - Environmental objectives and plans for achieving them } \\
\text { (Clause 6.2) } \\
\text { - Operational control (Caluse } 8.1 \text { ) } \\
\text { - Emergency preparadness and response (Clause } 8.2)\end{array}$ & $\begin{array}{l}\text { - } \text { Compliance obligations records (Clause 6.1.3) } \\
\text { - Records of training, skills, experience and qualifications } \\
\text { (Clause } 7.2 \text { ) } \\
\text { - Evidence of communication (Clause } 7.4) \\
\text { - } \text { Monitoring and measurement results (Clause 9.1.1) } \\
\text { - Internal audit programs (Clause 9.2) } \\
\text { - Results of internal audits (Clause 9.2) } \\
\text { - Results of the management review (Clause 9.3) } \\
\text { - Results of corrective actions (Clause 10.1) }\end{array}$ \\
\hline
\end{tabular}


by ISO 14001:2015, the list operational controls needed to be updated with current risk assessment method as described above. Some operational controls were discarded because the corresponding environmental aspects were no longer considered significant and there was a need for additional operational controls for new significant environmental aspects.

Copper ore mill have to considered cost effectiveness to be one of the most important characteristic of the operational control, and tried to apply this new approach when developing new and updating old operational controls. Its included every process owners to defining operational controls for their own processes. And it was beneficial because they knew exactly what would be the most effective control, and how much training would be needed for the employees who would be applying these controls, also awareness is considered to be one of the key success factors in applying the operational controls.

\section{Environmental Performance}

Copper ore mill wanted to have a system of monitoring and measuring that could provide information on the overall condition of EMS. Internal audits was perceived to be a robust and complicated approach because took too much time and effort, and they needed some information on these topics as a more frequent pace. That is why copper ore mill have to develop keys environmental performance indicators for each operational control to determine its performance.

And the top management required reports on the operational controls performance to be produced on a monthly basis. This is not a requirement of the EMS, but it had proven to be a useful tool for getting a clear picture on what was going on in the standard.

\section{Control of Documented Information}

Information management includes developing and applying information and strategy policy; data creation and management; information processing; storage and transfer; and information use (Maceviciute and Wilson, 2002). Technically, information management covers all system and processes such as document management; record management; technical infrastructure used to support information management programs (Reddy et al, 2009). In management point of view, infor- mation management is an organizational, social, cultural and strategic factor that needs to be paid attention to in improving information in organization (Robertson, 2005).

\section{Measuring and Reporting}

Change management, through continuous improvement and environmental management review model is depicted in figure 2 . The results of management review have to be demonstrated in meeting the requirements of ISO 14001:2015. The process of change into ISO 14001:2015 environmental management system passes through a transition period from current situation towards the expected situation to be achieved in the future.

Transition period needs specific management structure and activities (Cummings and Worley, 2009). This transition period needs: activity planning and commitment planning. The planning is explained until the most specific things. As a result, organization members have a clear direction on the objective and priority of the works to be done. After the planning is done, a development of strong commitment from all organization members is needed to make a change, so that the change can be done successfully. After the change is done by the organization, the next item to be done is to keep improving the spirit to change, so that it does not lose the momentum to keep doing change so that ISO 14001:2015 implementation can fulfill the need and objectives of copper ore mill in its environmental management.

Maximum result achievement in an organization must be followed by change management. The change can be done continuously to serve the needs from organization management or consumers, depending on the factors affecting them, either internal or external factors. Thus, organization performance measurement can be seen from the management success in managing their organization. The success of environmental management system depends on the leadership by the top management; commitment from all levels and functions; integrating the environmental management system into the organization, and putting in environmental management into management system as a whole.

Strategic step in implementing change management in developing organization can be done with a change at organization level where ISO 14001:2015 implementation is adaptive upon the change of international management system stan- 
dards to establish excellence and to achieve the objectives in environmental management. Clause 6.1 .4 , i.e. planning action on identifying risks, opportunities and compliance obligation, has added a column on environment, legislation and regulation aspects, where organization can show if there are problems that can be procedurally controlled (in the form of operational procedures or instructions). Organizationally, they are controlled through trainings, consultations, new employee trainings, awareness, etc. and control through supervision (inspections, checks, measurements, records) or technical control is managed. Clause 10, i.e. continuous improvement, is a part of change management that includes a list of all corrective actions that can show the steps related to the risk of identified change.

\section{DISCUSSION}

The first step to be done in order to implement EMS ISO 14001:2015 in Copper ore mill is to conduct change management, where this type of change is a planned transitional change. Change management planning starts with: defining the context of organization, interested parties, scope of the EMS, leadership and reviewing the environmental policy, and aligning EMS objectives with the company's strategy.

The next step starts with environmental performance planning, which consists of: risk and opportunity assessment, identifying and evaluating environmental aspect, determining compliance obligations, operational control, and environmental performance. After both stages are completed, information management design planning can be made, which includes: control of documented information, measuring and reporting.

This stage provides ease for other organization that has previously applied EMS ISO 14001, where the organization must also conduct change transition into version 2015 standard. Furthermore, environmental performance management shall be different between an organization and another, depending on the business process that refers to its life-cycle perspective and also on the identification of environmental aspects as well as risk and opportunity assessment in the organization.

The transition process of ISO 14001:2015 implementation was three years since the standards were published in 15 September 2015, so the end of transition process should be 15 September 2018. Transition is an opportunity and what copper ore mill needs to do is to:

1. Take a completely look at the EMS;

2. Highlight the key change as opportunity to improvements;

3. Make changes to documentation as part of information management by web based application to reflect new structure;

4. Implement new requirements on leadership, risk and context the organization; assume every control may have changed and carry out an impact assessment.

\section{REFERENCES}

1. Andersen, D, Andersen, L.A. 2001. Beyond Change Management. San Fransisco: Jossey-Bass, Inc.

2. Cummings, TG, Worley, CG. 2009. Organization Development \& Change. South-Western Cengange Learning, Ohio.

3. Davidson, J. 2009. The Complete Ideal's Guides: Change Management. Prenada Media Group, Jakarta.

4. Firth K, Smith K., Sakallaris, BR, Bellanti, DM. 2015. Healing, a Concept Analysis. Global Advance Health Medicine, 4(6): 44-50.

5. International Standard Organization (ISO)-a. Introduction to ISO 14001:2015. https://www.iso.org/ files/live/sites/isoorg/files/archive/pdf/en/introduction_to_iso_14001.pdf.

6. International Standard Organization (ISO)-b, 2015. Environmental Management System - Requirements with Guidance for Use. ISO 14001:2015, Geneva.

7. International Standard Organization (ISO)-a, 2006. Environmental Management - Life Cycle Assessment: Principles and Framework. ISO 14040:2006, Geneva.

8. International Standard Organization (ISO)-b, 2006. Environmental Management - Life Cycle Assessment: Requirements and Guideline. ISO 14044:2006, Geneva.

9. Jr. Bird, FE, Germain, LG. 1996. Loss Control Management, Practical Loss Control Leadership. Revised Edition, Det Norske Veritas (USA), Inc., Georgia.

10. Maceviciute, E, Wilson, TD. 2002. The Deveopment of the Information Management Research Area. Information Research, 7, http://InformationR.net/ir/7-3/paper133.html.

11. Metcalf, BA., Meltcalf, JA. 2005. The Crucial of leadership in Meeting the Challanges of Change. 
Journal of Business Perspective, 27-39.

12. Newton, R. 2007. Managing Change: Step by Step All You Need to Build A Plan and Make It Happen. Ashford Colour Press, Ltd., London.

13. Nuoppopen, A. 2010. Methods of Concept Analysis - a Comparative Study. LSP Journal, 1(1): 4-12.

14. Robertson, J. 2005. 10 Priciples of Effective Information Management. Step Two Design Pty. Ltd. http:// www.steptwo.com.au/papers/kmc_effectiveim/.

15. Shehabi, E. 2016. Application of the New Version of the Environmental Management System, the Impact on Enterprose Development. Anglisticum Journal (AJ), 5(5): 85-91.

16. Susanto, A, Putro, EK, Wulan, RN, Yochu, WE 2012. Globally Harmonized System (GHS) Implementation and Management of Hazardous Susbtances (B3) in Concentrating Division PT Freeport Indonesia. 1st International Conference on Sustainable Agriculture and Environment. Solo: Sebelas Maret University, 302-308.
17. Susanto, A. 2017. Design of Information Management for Environmental Performance Management based on ISO 14001:2015 in Concentrating Division PT Freeport Indonesia. Graduate Program Thesis, Institut Teknologi Bandung, Bandung.

18. Susanto, A, Wulan, RN, Putro, EK. 2016. Used Oil Utilization for Lime Production as Hazardous Waste Minimization. International Journal of Waste Resources, 6(4): 252.

19. Susanto, A, Suryanegara, D, Putro, E.K. 2013. Indoor Air Quality Control Laboratory Concentrating Division PT Freeport Indonesia. The Second International Conference on Sustainable Infrastructure and Built Environment. Institut Teknologi Bandung, Bandung, 373-376.

20. Wallace, M J, and Szilagyi, AD. 1982. Managing Behavior in Organizations. Scott Foresman \& Company, London.

21. Yukl, G. 2002. Leadership in Organizations. Prentice Hall International, New York. 